\title{
Insulin-like growth factor-1 receptor expression in oral squamous cell carcinoma
}

\author{
Oral yassı hücreli karsinomda insulin benzeri büyüme faktörü-1 ekspresyonu
}

\author{
Boby K. Joseph, Devipriyaa B. Sundaram
}

Department of Diagnostic Sciences, Faculty of Dentistry, Kuwait University, Kuwait

\begin{abstract}
Objectives: The Insulin-like growth factor-I receptor (IGF-1R) plays critical roles in cancer development, proliferation, motility and survival. IGF-1R over expression is frequently found in various tumours and is often associated with an aggressive phenotype. Hence, the aim of the present study was to examine the expression of IGF-1R in normal oral mucosa, fibroepithelial polyps, dysplastic oral mucosa and well-differentiated squamous cell carcinomas.
\end{abstract}

Materials and methods: A 3-layered streptavidin peroxidase immunohistochemical method was used to detect the expression of IGF-1R in normal oral mucosa, fibroepithelial polyps, dysplastic oral mucosa and well-differentiated squamous cell carcinomas.

Results: All squamous cell carcinomas (15 out of 15 patients) showed intense immunoreactivity for IGF-1R. Moderate immunoreactivity was seen in dysplastic oral lesions (12 out of 12 lesions) with positive staining in the prickle cell layer. The staining distribution in the benign lesions (14 out of 14 lesions) was weaker and similar to that seen in normal oral mucosa (10 out of 10 samples) when compared to squamous cell carcinomas and dysplastic lesions.

Conclusions: Our results demonstrate increased IGF-1 receptor expression in oral squamous cell carcinomas which suggests that IGF-1 may have an important role in the development of oral cancer. J Clin Exp Invest 2011; 2 (4): 354-361

Key words: Growth factors, insulin-like growth factor receptor, epithelial dysplasia, Oral squamous cell carcinoma, immunohistochemistry

\section{INTRODUCTION}

Oral squamous cell carcinoma is by far the most common type of cancer of the oral cavity, representing more than $90 \%$ of all oral cancers. Despite numerous advances in diagnosis and treatment of oral squamous cell carcinoma (OSCC), the prognosis remains poor. A better understanding of the

\section{ÖZET}

Amaç: İnsülin benzeri büyüme faktörü-1 reseptörü (IGF$1 R$ )'ün kanser gelişiminde, proliferasyon ve sağkalımda önemli rolleri vardır. IGF-1R aşırı salınımı sıklıkla çeşitli tümörlerde gözlenir ve çoğunlukla agresif fenotiple birliktedir. Bu çalışmanın amacı normal ağız içi mukozası, fibroepitelyal polipler, displastik ağız mukozası ve iyi diferensiye yassı epitel hücreli karsinom'da IGF-1R ekspresyonunu araştırmaktır.

Gereç ve yöntem: IGF-1R ekspresyonunu normal ağız içi mukozası, fibroepitelyal polipler, displastik ağız mukozası ve iyi diferensiye yassı epitel hücreli karsinom'da araştırmak için üç basamaklı bir streptavidin peroksidaz immunohistokimyasal yöntem kullanıldı.

Bulgular: Yassı epitel hücreli karsinomların tümü (15 hasta) IGF-1R için yoğun immunoreaktivite gösterdi. Orta düzeyde immun reaktivite "prickle" hücre lezyonu tabakasıyla birlikte displastik ağız içi lezyonlarda (12 hastadan 12 'sinde) görüldü. Selim lezyonlarda (14 hasta) boyama dağılımı daha zayıftı ve yassı epitel hücreli karsinom ve displastik lezyonlarla kıyaslandığında, normal ağız mukozasında (10 örnek) görülene benzer şekilde idi.

Sonuç: Bulgularımız, ağız içi yassı epitel hücreli karsinom ve oral kanser gelişiminde önemli rolleri olabileceğini telkin eder tarzda, IGF-1R'nin ekspresyonunun arttığını göstermektedir.

Anahtar kelimeler: Büyüme faktörleri, insülin-benzer büyüme reseptörü, epitelyal displazi, ağız içi yassı epitel hücreli karsinom, immunohistokimya

molecular basis of tumour characteristics plays an important role in cancer therapeutics. Recently, the discovery of a number of subcellular targets in cancer cells has led to "molecular targeted cancer therapies". This targeted approach aids the clinician in identifying high-risk lesions for early detection and to individualize the management of OSCC patients. 
Insulin-like growth factor (IGF) signaling axis is one such newly emerging target. ${ }^{1}$

The Insulin-like growth factors are a family of mitogenic proteins that control growth, differentiation and the maintenance of differentiated function in numerous tissues. The IGF family consists of ligands (insulin, IGF-1 and IGF-2), receptors (IGF$1 R$, IGF-2R/mannose-6-phosphate and insulin receptor, IR) and six regulatory IGF-binding proteins (IGFBP 1-6). In addition to these "classic" members, the IGF system also consists of "non-classic" members, which include additional receptors (the insulinreceptor related receptor and Insulin- IGF1 hybrid receptor) and a growing number of IGFBPs-related proteins. $^{2}$

The insulin-like growth factor-1 receptor (IGF$1 \mathrm{R}$ ) belongs to the family of transmembrane tyrosine kinase receptors (RTK) that is structurally and functionally related to the insulin receptor. ${ }^{3}$ It is widely expressed in normal human tissues except hepatocytes and mature B-cells and is involved in embryonic development and postnatal growth. ${ }^{4}$ It binds primarily to IGF-1, IGF-2 and insulin with lower affinity for the latter two ligands (500- to 1,000-fold less potent). IGF-1R activation triggers a cascade of reactions involving two signal transduction pathways. ${ }^{5}$ Activation of IGF-1R has been reported to stimulate proliferation, survival, transformation, metastasis, and angiogenesis. ${ }^{6,7}$

IGF-1R levels are tightly regulated by the concerted action of secreted factors (eg. peptide and steroid hormones, growth factors and cytokines) and cellular factors (eg. transcription factors, oncogenes and tumour suppressors) that can either stimulate or inhibit IGF-1R biosynthesis (Fig.1). The balance between these stimulatory and inhibitory factors might ultimately determine the level of expression. ${ }^{8}$ There is a growing body of evidence that activation of growth factor receptors is a mechanism by which tumor suppressor genes and oncogenes modulate cellular proliferation and consequently the formation and/or growth of tumors.

There is considerable evidence identifying the IGF-1R having important roles in promoting carcinogenesis by increasing the risk of cellular turnover, thereby increasing the susceptibility of cells to malignant transformation. Samani et al. have reviewed the evidence on the role of the IGF system in malignancy. ${ }^{9}$ Pollak (2000) provided a hypothesis concerning the mechanism by which IGF physiology influences risk of common epithelial cancers including those of breast, prostate, lung and colon. ${ }^{10}$ Both preclinical research and clinical investigations have implicated the IGF-1R and its ligands (IGF-1 and IGF-2) in the development and progression of a number of human cancers. ${ }^{11,12}$

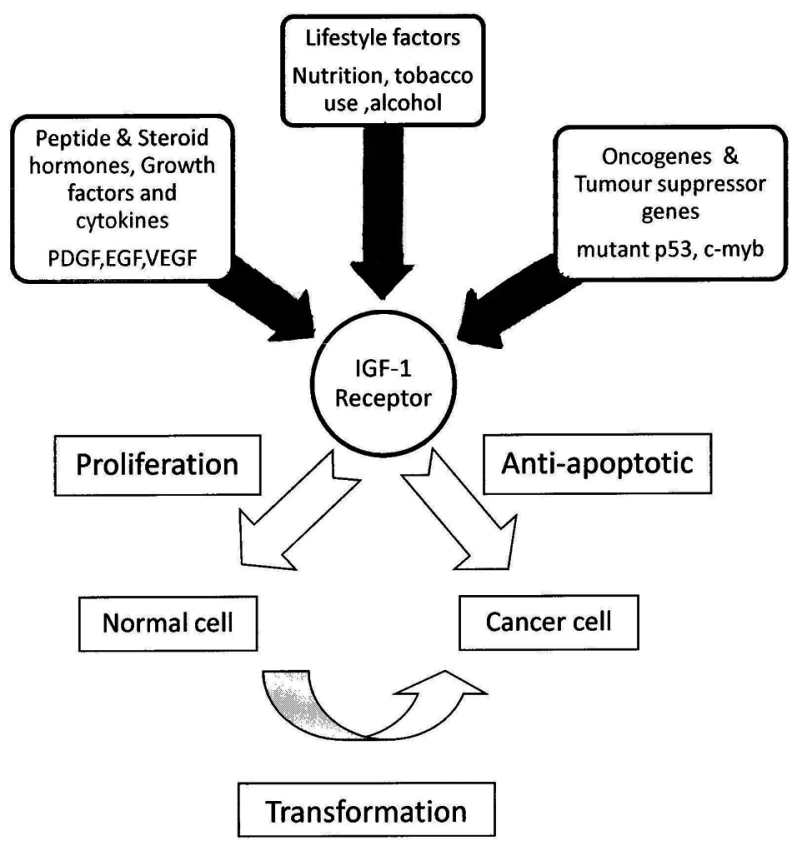

Figure 1. Factors influencing IGF-1R expression and its effects.

IGF-1R over expression is frequently found in a broad range of tumours (breast, colon, lung, ovarian, prostate) and is often associated with an aggressive phenotype. In tumors, such as colorectal, cervical, non-small cell lung, gastrointestinal and pediatric cancers, the role of IGF-1R is especially critical. Selected examples of IGF-1R involvement in human cancer have been reviewed by Werner and Bruchim in 2009. ${ }^{13}$

Hellawell et al. detected a significant upregulation of IGF-1R expression level in primary prostate cancer cells in comparison to benign prostatic epithelium. ${ }^{14}$ IGF-1R expression increased during the progression of colorectal adenoma to carcinoma. ${ }^{15}$ The progression from benign nevi to malignant melanoma was also accompanied by the upregulation of IGF-1R expression. ${ }^{16}$

However, the potential role of IGF in the development of oral carcinomas is less clear. Hence, the aim of this study was to examine IGF-1 receptor expression in normal, benign, dysplastic and malignant lesions of the oral mucosa using immunohistochemistry.

\section{MATERIALS AND METHODS}

A retrospective, immunohistochemical study was done using the 3-layered streptavidin peroxidase 
method to detect IGF-1R expression in normal oral mucosa, benign fibroepithelial polyps, oral epithelial dysplasia and oral squamous cell carcinoma.

\section{Antibody to IGF-1 receptor}

Anti-human IGF-I receptor polyclonal antibody which was raised in chicken against the alpha-subunit of the human IGF-1 receptor was purchased from Upstate Biotechnology, USA. This antibody does not cross-react with IGF-2 receptor, with the insulin receptor, or with IGF binding proteins.

\section{Tissue specimens}

Lesional tissue was available from 15 patients with oral squamous cell carcinoma (SCC), 12 patients with oral epithelial dysplasia and 14 patients with benign fibroepithelial polyps (FEP). All the tissues were formalin-fixed, paraffin embedded archival material. Hence variations due to differences in fixation were not controlled. Diagnoses were confirmed following re-examination of haematoxylin and eosin stained sections. Normal oral mucosa obtained during the removal of mandibular third molars from 10 patients were used for comparison.

\section{Immunohistochemistry}

Deparaffinized sections were processed for the detection of IGF-1R by the specific 3-layered streptavidin peroxidase method. Sections were incubated with $0.5 \%(\mathrm{v} / \mathrm{v})$ hydrogen peroxide for ten minutes at $20^{\circ} \mathrm{C}$ to block endogenous peroxidase activity. Nonspecific protein binding was eliminated by incubation with $1 \%$ normal horse serum for thirty minutes.

Sections were incubated overnight at $4^{\circ} \mathrm{C}$ with chicken anti-human IGF-1 receptor (Upstate Biotechnology, New York, USA) followed by incubation with donkey anti-chicken biotinylated IgG (Dako Corporation, USA) diluted 1:200 in PBS for 1 hour at room temperature. Slides were then subjected to incubation with streptavidin horseradish peroxidase complex (Amersham, Australia), diluted 1:100 in PBS for 1 hour at room temperature. Then, the slides were treated with $0.05 \mathrm{mg} / \mathrm{ml}$ of diaminobenzidine in PBS containing $0.05 \% \mathrm{H}_{2} \mathrm{O}_{2}$ for five minutes. Between each step sections were washed two times in PBS. All incubations were performed in a humidified chamber. Sections were left uncounterstained or counterstained in Mayer's haematoxylin, dehydrated and mounted.

Controls included omission of the primary antibody(negative control) and sections of rat gastric mucosa (positive control). Level of immunore- activity was graded as weak $(+)$, moderate $(++)$ and intense $(+++)$ by two independent observers.

An interrater reliability analysis using the kappa statistic was performed to determine the consistency among the two observers.

\section{RESULTS}

\section{Distribution of IGF-1R expression}

The IGF-1R immunoreactivity found in normal, benign, dysplastic and malignant lesions is detailed in Table.1. The positivity of the staining was confirmed in gastric epithelium where the differential expression of IGF-1 receptor in the zymogen cells of the gastric glands is well characterized.

Table 1. Insulin-Like Growth Factor-1 Receptor expression in normal, benign, dysplastic and malignant oral epithelium.

\begin{tabular}{lll}
\hline Tissue sample & $\begin{array}{c}\text { Number } \\
\text { of cases }\end{array}$ & $\begin{array}{l}\text { Level of } \\
\text { Immunoreactivity }\end{array}$ \\
\hline Normal oral mucosa & 10 & + \\
Benign oral lesions & 14 & + \\
$\begin{array}{l}\text { Dysplastic lesions } \\
\text { Oral squamous cell } \\
\text { carcinomas }\end{array}$ & 12 & ++ \\
\hline
\end{tabular}

+ weak intensity ++ moderate intensity +++ strong intensity

\section{IGF-IR localization in normal oral tissue and fibroepithelial polyps}

IGF-IR was detected in all the normal oral tissue (Fig.2) and benign fibroepithelial polyps (Fig.3). The distribution of the IGF-1R were purely within the epithelial layer and the staining was consistent throughout the epithelial layer. All other tissue components stained negatively to the immunohistochemical stain. The intensity for normal oral tissue and benign epithelium was similar and was weak (+).

\section{IGF-IR localization in dysplastic oral mucosa}

In the dysplastic oral lesions, majority of which showed severe dysplasia, a positive staining was observed in the prickle cell layer (Fig.4). The moderate amount $(++)$ of IGF-1R was seen within the stratum spinosum of the epithelium. The staining was almost consistent throughout the epithelium layer; the altered nuclear/cytoplasmic ratio could be seen clearly due to the stain surrounding the nucleus in some of the cells within the epithelium layer. 


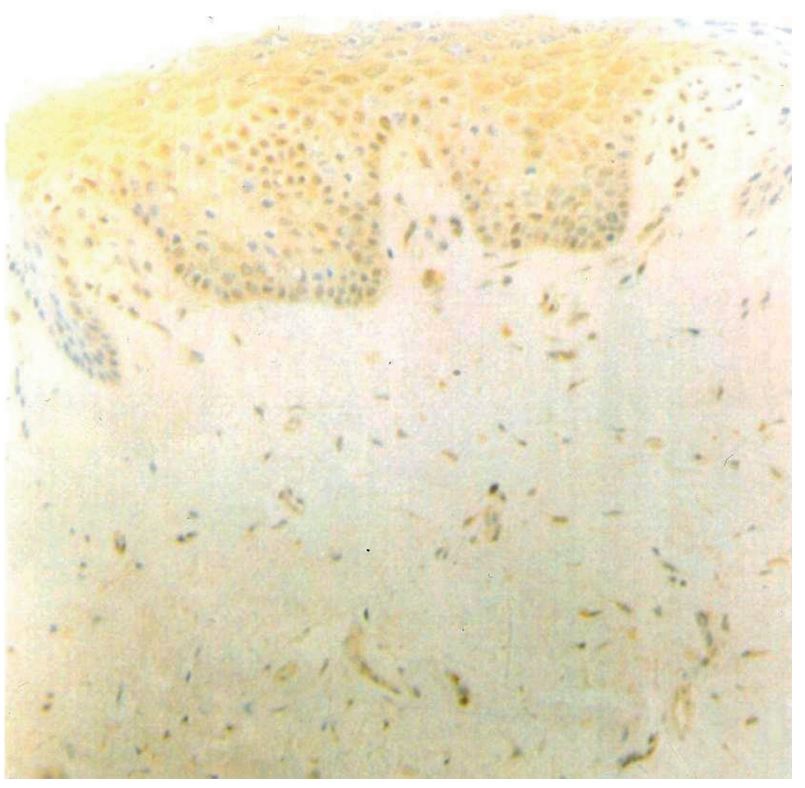

Figure 2. Section of normal oral mucosal epithelium stained immunohistochemically for insulin-like growth factor-1 receptor showing weak immunoreactivity throughout the epithelium. 10x magnification.

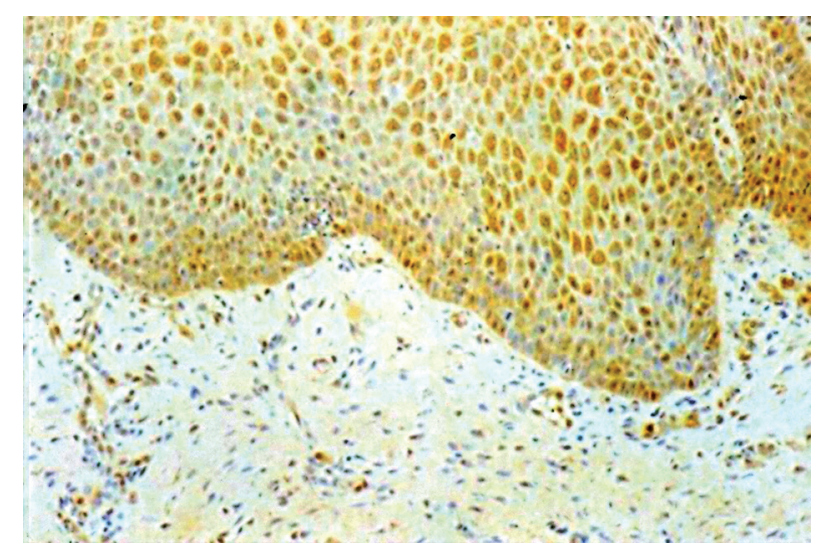

Figure 3. Section of benign fibroepithelial polyp stained immunohistochemically for insulin-like growth factor-1 receptor showing weak immunoreactivity in the epithelium. 20x magnification.

\section{IGF-IR localization in Squamous cell carcinomas}

All the SCCs showed intense (+++) immunoreactivity for IGF-IR. The staining reaction was variable, the most intense staining were in the cells at the invading tumour margin and in the cells at the periphery of invading tumour islands (Fig. 5). This staining pattern showed a marked contrast with adjacent non staining connective tissue. The results showed that well differentiated SCCs tumour islands were staining much stronger and leaves a clear space in the middle which represent the keratin pearls (Fig.
6). The cellular staining characteristics of severe dysplasia were also observed in the SCCs, strong staining in the cytoplasmic areas surrounding the weakly stained nucleus at the invading tumour margin.

Incubation of sections with non-immune serum, or after omission of the primary antibody or the secondary anti-serum, did not produce immunohistochemical staining (Fig. 7).

The interobserver reliability was found to be Kappa=1.0 $(p<0.001)$. There was complete agreement between the observers.

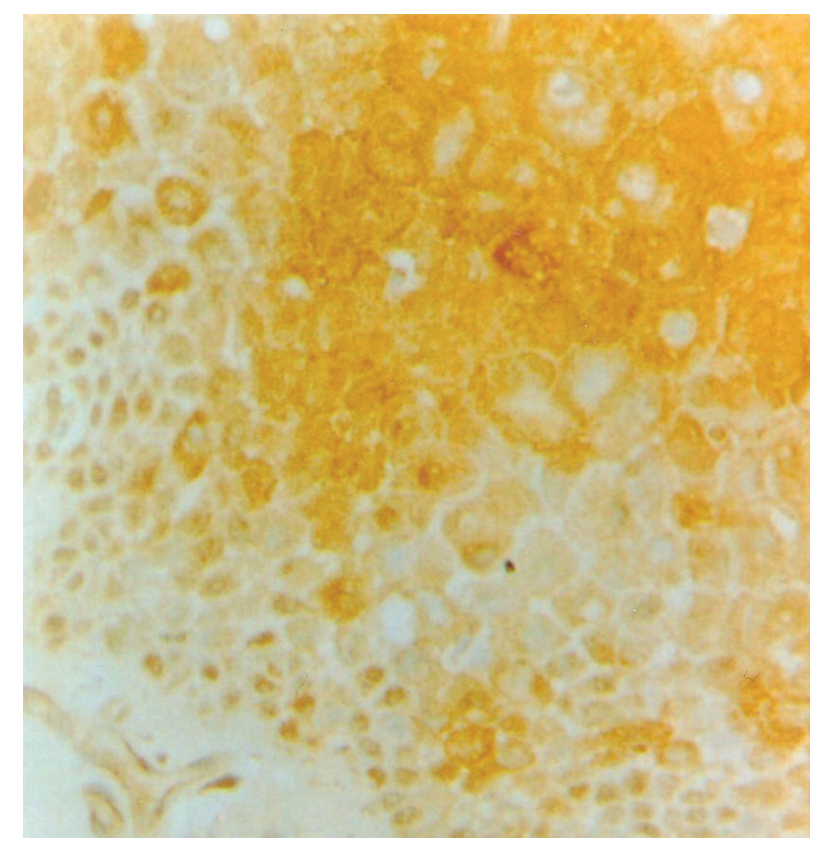

Figure 4. Section of dysplastic epithelium stained immunohistochemically for IGF-1R showing moderate immunoreactivity. 40x magnification.

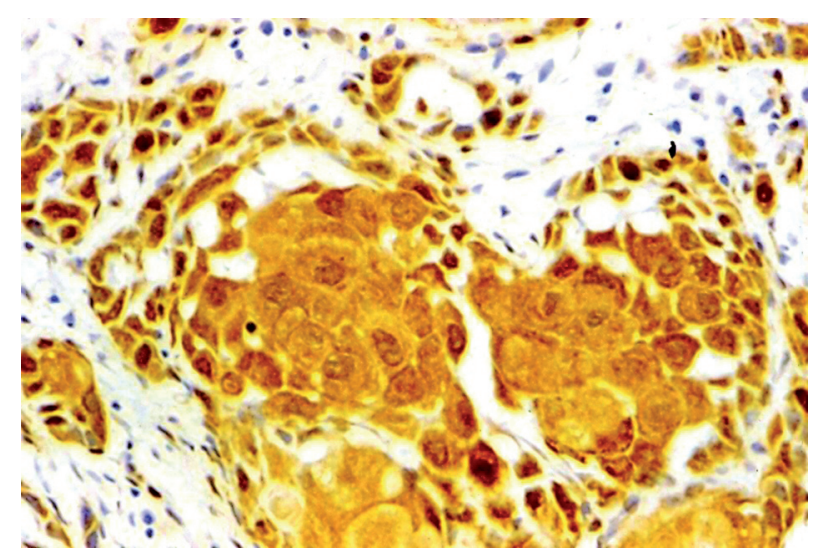

Figure 5. Section of oral squamous cell carcinoma stained immunohistochemically for IGF-1R showing intense immunoreactivity. 40x magnification. 


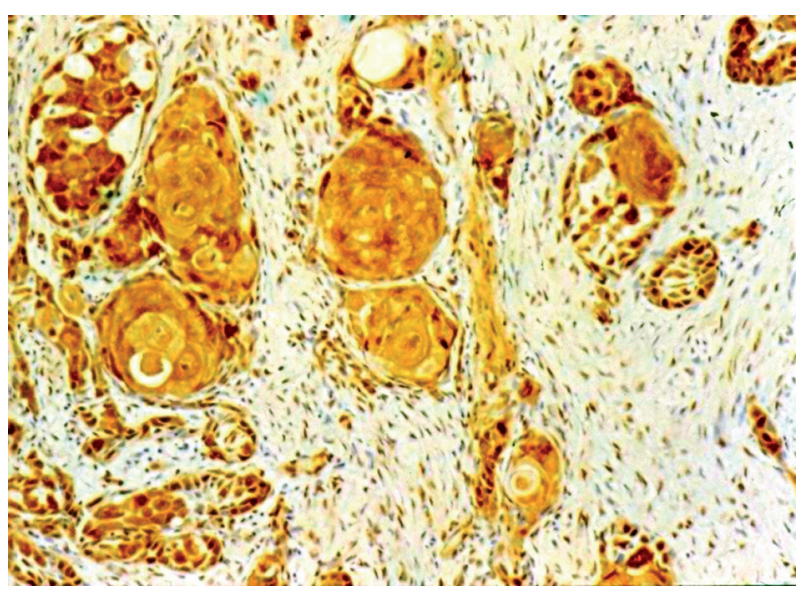

Figure 6. Section of oral squamous cell carcinoma stained immunohistochemically for IGF-1R showing strong immunoreactivity in the periphery of the tumour islands. $20 \mathrm{x}$ magnification.

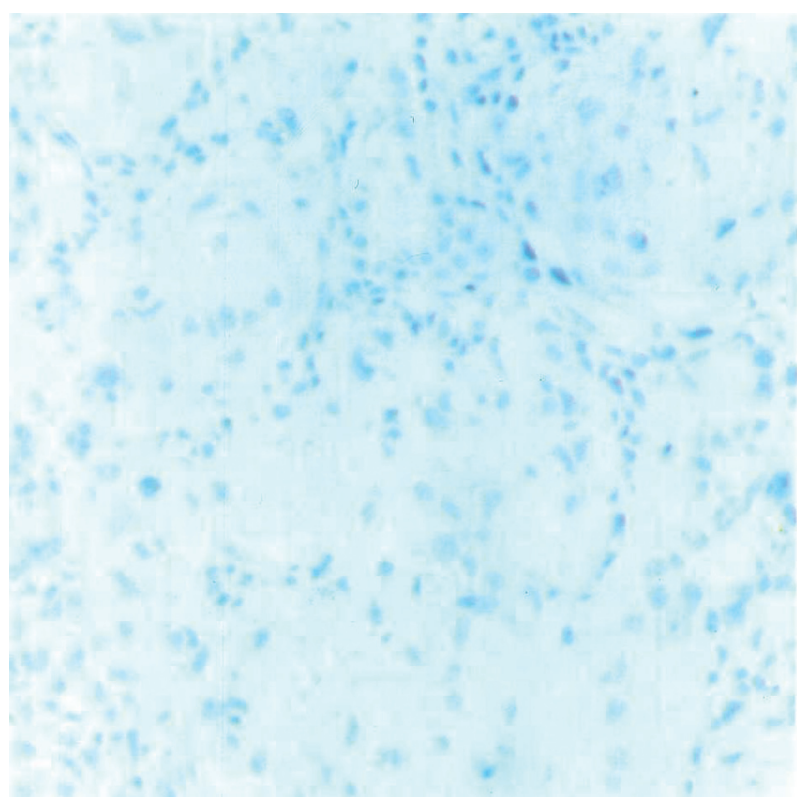

Figure 7. Section of normal oral mucosal epithelium stained immunohistochemically after omission of primary antibody showing absence of immunostaining (negative control). 40x magnification.

\section{DISCUSSION}

The role of the IGF-1 receptor in normal mammalian development is exemplified by the work of Efstratiadis and co-workers on mice that carried a null mutation for the IGF-I receptor gene. ${ }^{17,18}$ The growth in-utero of these mice is severely inhibited and the mice die immediately after birth. Fibroblasts derived from these mice (R-cells) cannot grow in IGF-1-supplemented serum-free medium whereas mouse fibroblasts with functional IGF-1 receptors (W cells) are capable of growth. ${ }^{19}$ In $10 \%$ serum, Rcells grow, but at a slower rate than the $\mathrm{W}$ cells. This suggested that IGF-1R is not an absolute requirement for growth, although it is required for optimal growth.

In addition to its important role in normal growth, it is now well established that the IGF system has a fundamental role in malignant transformation. ${ }^{20,21,22}$ This notion is supported by both clinical and experimental evidence, including the widespread observation that ligands and receptors are usually overexpressed by most primary tumours and transformed cell lines..$^{23,24,25}$

IGF-1R is involved in transformation and proliferation of malignant cells, in prevention of apoptosis and in the maintenance of the malignant phenotype of tumour cells as well as it has an important function in tumour cell protection against anti-tumour therapy. The transforming function of IGF-1R depends on its mitogenic and anti-apoptotic activities.

The protective effect of activated IGF-1R on cell survival mainly depends on the regulation of the main elements in the apoptotic cascade. Caspase- 3 plays a key role in the apoptotic process as the main effector of enzymatic cleavage. It is controlled by certain other proteins, pro-apoptotic Bax and the anti-apoptotic Bcl-2. ${ }^{26}$ IGF-1R is able to indirectly inhibit caspase -3 activity by activation of $\mathrm{Bcl}-2$ and inhibition of Bax. ${ }^{27}$

In an in-vivo model, Rescnicoff and co-workers have demonstrated that a decrease in the number of IGF-1 receptors, achieved using antisense oligomers, resulted in massive apoptosis of tumour cells. ${ }^{28}$ Thus, the activation of IGF-1R may rescue cell populations from apoptosis that, in the absence of growth factor are tagged for elimination. ${ }^{29}$ Mitsiades et al (2004) demonstrated that IGF-1R is universally expressed in various hematologic (multiple myeloma, lymphoma, leukemia) and solid tumor (breast, prostate, lung, colon, thyroid, renal, adrenal cancer, retinoblastoma, and sarcoma) cells. They also provided in-vivo proof of principle for therapeutic use of selective IGF-1R inhibitors in cancer. ${ }^{30}$

Growth of cancer cells in culture, that is breast cancer cell lines and Wilms' tumor cells, can be inhibited by blocking the action of IGF-I with antibodies to the IGF-I receptor. ${ }^{31,32,33}$ Furthermore, by using antisense IGF-I receptor mRNA strategies, investigators have shown reduced mitogenesis in a cultured human rhabdomyosarcoma cell line and breast cancer cell lines. ${ }^{34,35}$ In addition, a dominant negative mutation involving deletion of most of the 
ß-subunit of the IGF-I receptor inhibited tumor formation by Rat-1 fibroblasts. ${ }^{36}$ All of these findings are consistent with the hypothesis that functional IGF-I receptors are necessary for tumor formation and progression.

The IGF system of ligands, receptors and binding proteins is linked to a number of physiological and pathological oral processes. Werner and Katz discussed the emerging role of IGFs in oral biology. ${ }^{2}$ They are involved in the biology of several periodontal structures and various aspects of salivary gland homeostasis. The IGF-1 signaling axis is known to have a role in the developmental regulation of structures of the oral cavity. ${ }^{37,38}$ Brady et al. showed that IGF-1 protects human oral buccal mucosal cells from sodium nitroprusside -induced apoptosis and thus provided further evidence to the significance of IGF proteins in the possible development of oral cancer. ${ }^{39}$

There have been studies on the implications of plasma levels of IGF and IGFBPs in control and oral cancer patients. Bhatavdekar et al. found low levels of IGF-1 in patients with advanced tongue cancer when compared to controls. However, they failed to establish a predictive link between IGF levels and outcome. ${ }^{40}$ Brady et al. showed that, in contrast to other cancers such as breast, prostate and bowel, the serum levels of IGF-1 and IGFBP-3 were significantly lower in oral cancer patients than in controls. However, serum levels of IGFBP-1 and IGFBP-2 were elevated. ${ }^{41}$ Papadimitrakopoulou et al. showed that downregulation of IGFBP-3 is a highly significant predictor of poor outcome for patients with tongue cancer. ${ }^{42}$

Previous studies have described the expression of various proteins of the IGF system in normal oral and epithelial tumour cell lines. Brady et al. suggested that production of IGF-2 together with over-expression of IGF-1R may be important components in controlling the proliferation of oral carcinoma cells. ${ }^{43}$

In patients with head and neck cancer, high serum levels of IGF-1 and extreme low/ high levels of IGFBP 3 predict risk of second primary tumours. ${ }^{44}$ Barnes et al. showed that IGF-1R expression is increased in human head and neck cancer and that IGF-1R signaling significantly influences proliferation, motility and tumorigenicity of human head and neck cancer cell lines. ${ }^{1}$

Slomiany et al. demonstrated the potential for co-targeting the IGF-system and Epidermal Growth Factor Receptor (EGFR) in head and neck squamous cell carcinoma. ${ }^{45}$ Reszec et al (2004) evaluated the expression of IGF-1R in primary tumours and lymph node metastases of oral cancers by immunohistochemistry. They suggested an association between IGF-1R expression in primary tumours and metastatic ability. ${ }^{46}$

Tumour IGF-IR expression may, therefore, has profound biological and prognostic significance. Control of the IGF-1 receptor number at the cell surface is an important level at which IGF action can be regulated. As the number of receptors increases, so does the effect that IGF-1 exerts. More IGF-1 receptor activity means increased mitogenic signaling and increased likelihood of survival from apoptosis. ${ }^{43}$

In our study, we have demonstrated the localization of IGF-1R in normal oral tissue, fibroepithelial polyps, oral dysplastic lesion and squamous cell carcinoma and have confirmed the positive association with cell division process. The difference in distribution of IGF-1R is observed and malignant oral cancer such as SCC was stained much stronger than the benign conditions such as dysplasia and fibro epithelial polyp. Previously, Frier et al. observed 2.5 times higher expression of IGF-1R in malignant colon tissue than in normal tissue and Weber et al. observed an overexpression of IGF-1R in $91 \%$ of all colon carcinomas. ${ }^{47,48}$ More importantly, using immunohistochemistry, IGF-1R can be seen in appreciable levels in normal oral tissue, an observation which should be considered if IGF-1R is deemed to be a potential therapeutic target. Previously, in the study by Reszec et al., 32 out of 57 (56.1\%) of the oral squamous cell cancers showed IGF-1R positive immunoreaction whereas all 15 cases showed intense IGF-1R immunoreactivity in our study. ${ }^{46}$ These results indicate that IGF-1R is present most concentrated in cell populations of dividing epithelium and followed by the increase in cell division, the amount of IGF-1R also increased.

In conclusion, these findings support the concept that IGF-1R is important for growth of normal cells and uncontrollable growth in transformation and/or tumorigenesis and, as such, could be a preferred target for therapeutic interventions.

\section{REFERENCES}

1. Barnes CJ, Ohshiro K, Rayala SK, El-Naggar AK, Kumar R. Insulin-like growth factor receptor as a therapeutic target in head and neck cancer. Clin Cancer Res 2007; 13(15): 4291-99.

2. Werner $\mathrm{H}$, Katz J. The emerging role of the insulinlike growth factors in oral biology. J Dent Res 2004; 83(11): 832-36. 
3. Le Roith D, Werner H, Beitner-Johnson D, Roberts CT Jr. Molecular and cellular aspects of the insulin-like growth factor I receptor. Endocr Rev 1995; 16(2):14363.

4. Valentinis $B$, Baserga $R$. IGF-1 receptor signaling in transformation and differentiation. Mol Pathol 2001; 54(3): 133-7.

5. Ullrich A, Schlessinger J. Signal transduction by receptors with tyrosine kinase activity. Cell 1990; 61(2): 203-12.

6. Baserga R, Peruzzi F, Reiss K. The IGF-1 receptor in cancer biology. Int J Cancer 2003; 107(6): 873-877.

7. Le Roith D, Roberts CT Jr. The insulin-like growth factor system and cancer. Cancer Lett 2003; 195(2):12737.

8. Werner $\mathrm{H}$, Maor S. The insulin-like growth factor- 1 receptor gene: a downstream target for oncogene and tumour suppressor action. Trends Endocrinol Metabol 2006; 17(6): 236-42.

9. Samani AA, Yakar S, Le Roith D, Brodt P. The role of the IGF system in cancer growth and metastasis: overview and recent insights. Endocr Rev 2007; 28(1): 20-47.

10. Pollak M. Insulin-like growth factor physiology and cancer risk. Eur J Cancer 2000; 36(10): 1224-28.

11. Larsson O, Girnita A, Girnita L. Role of Insulin-like growth factor -1 receptor signaling in cancer. $\mathrm{Br} J$ Cancer 2005; 92(12): 2097-01.

12. Pollak MN, Schernhammer ES, Hankinson SE. Insulin-like growth factors and neoplasia. Nat Rev Cancer 2004; 4(7): 505-18.

13. Werner $\mathrm{H}$, Bruchim I. The insulin-like growth factor-1 receptor as an oncogene. Arch Physiol Biochem 2009; 115(2): 58-71.

14. Hellawell GO, Turner GD, Davies DR, Poulsom R, Brewster SF, Macaulay VM. Expression of the type 1 Insulin-like growth factor receptor is upregulated in primary prostate cancer and commonly persists in metastatic disease. Cancer Res 2002; 62(10): 294250.

15. Hakam A, Yeatman TJ, Lu L et al. Expression of insulin-like growth factor receptor-1 receptor in human colorectal cancer. Hum Pathol 1999; 30(10):1128-33.

16. Kanter-Lewensohn L, Dricu A, Girnita L, Wejde J, Larsson $\mathrm{O}$. Expression of insulin-like growth factor-1 receptor (IGF-1R) and p27Kip1 in melanocytic tumors: a potential regulatory role of IGF-1 pathway in distribution of p27Kip1 between different cyclins. Growth Factors 2000; 17(3):193-202.

17. Baker J, Liu JP, Robertson EJ, Efstratiadis A. Role of insulin-like growth factors in embryonic and postnatal growth. Cell 1993; 75(1): 73-82.

18. Liu JP, Baker J, Perkins AS, Robertson EJ, Efstratiadis A. Mice carrying null mutations of the genes encoding insulin-like growth factor-1 and type 1 IGF receptor. Cell 1993; 75(1): 59-72.

19. Sell C, Dumenil G, Deveaud C. Effect of a null mutation of the type 1 IGF receptor gene on growth and transformation of mouse embryo fibroblasts. Mol Cell Biol 1994; 14(6): 3604-12.

20. Coppola D, Ferber A, Miura M, et al. A functional insulin-like growth factor 1 receptor is required for the mitogenic and transforming activities of the epidermal growth factor receptor. Mol Cell Biol 1994; 14(7): 4588-95.

21. De Angelis T, Ferber A, Baserga R. Insulin-like growth factor 1 receptor is required for the mitogenic and transforming activities of the platelet-derived growth factor receptor. J Cell Physiol 1995; 164(1): 214-21.

22. Sell C, Rubini M, Rubin R, Liu JP, Efstratiadis A, Baserga R. Simian virus 40 large tumor antigen is unable to transform mouse embryonic fibroblasts lacking type-1 IGF receptor. Proc Natl Acad Sci USA 1993; 90(23): 11217-221.

23. Baserga R, Sell C, Porcu P, Rubini M. The role of the IGF-I receptor in the growth and transformation of mammalian cells. Cell Prolif 1994; 27(2): 63-71.

24. Kaleko M, Rutter WJ, Miller AD. Overexpression of the human insulin-like growth factor 1 receptor promotes ligand-dependent neoplastic transformation. Mol Cell Biol 1990; 10(2): 464-73.

25. Werner $H$, Le Roith $D$. The role of the insulin-like growth factor system in human cancer. Adv Cancer Res 1996; 68(2): 183-223.

26. Villa P, Kauffmann SH, Earnshaw WC. Caspases and caspase inhibitors. Trends Biochem Sci 1997; 22(10): 388-93.

27. Wang L, Ma W, Markovich R, Lee WL, Wang PH. Insulin-like growth factor 1 modulates induction of apoptotic signaling in $\mathrm{H} 9 \mathrm{C} 2$ cardiac muscle cells. Endocrinology 1998; 139(3): 1354-60.

28. Resnicoff M, Coppola D, Sell C. Growth inhibition of human melanoma cells in nude mice by antisense strategies to the type I insulin-like growth factor receptor. Cancer Res 1994; 54(18): 4848-50.

29. Werner H, Shalita-Chesner M, Abramovitch S, Idelman G, Shaharabani-Gargir L, Glaser T. Regulation of the insulin-like growth factor-I receptor gene by oncogenes and antioncogenes: Implications in human cancer. Mol Genet Metab 2000; 71(1-2): 315-320.

30. Mitsiades CS, Mitsiades NS, McMullan CJ, et al. Inhibition of the insulin-like growth factor receptor-1 tyrosine kinase activity as a therapeutic strategy for multiple myeloma, other hematologic malignancies, and solid tumors. Cancer Cell 2004; 5(3): 221-30.

31. Arteaga CL, Osborne CK. Growth inhibition of human breast cancer cells in vitro with an antibody against the type 1 somatomedin receptor. Cancer Res1989; 49(22): 6237-41.

32. Arteaga CL, Kitten LJ, Coronado EB, et al. Blockade of the type 1 somatomedin receptor inhibits growth in human breast cancer cells in athymic mice. J Clin Invest 1989; 84(5): 1418-23.

33. Gansler T, Furlanetto R, Gramling TS, et al. Antibody to type-1 insulin-like growth factor receptor inhibits 
growth of Wilm's tumour in culture and in athymic mice. Am J Pathol 1989; 135(6): 961-66.

34. Neuenschwander S, Schwartz A, Wood TL, Roberts CT Jr, Henninghausen L, Le Roith D. Involution of the lactating mammary gland is inhibited by the IGF system in a transgenic mouse model. J Clin Invest 1996; 97(10): 2225-32.

35. Shapiro DN, Jones BG, Shapiro LH, Dias P, Houghton PJ. Antisense-mediated reduction in insulin-like growth factor-1 receptor expression suppresses the malignant phenotype of a human alveolar rhabdomyosarcoma. J Clin Invest 1994; 94(3): 1235-42.

36. Prager D. Li HL, Asa S, Melmed S. Dominant negative inhibition of tumorigenesis in vivo by human insulinlike growth factor 1 receptor mutant. Proc Natl Acad Sci 1994; 91(6): 2181-85.

37. Amanso O, Iseki S. Expression, Iocalization and development regulation of insulin-like growth factor 1 mRNA in rat submandibular gland. Arch Oral Biol 1993; 38(8): 671-7.

38. Joseph BK, Savage NW, Daley TJ, Young WG. In situ hybridization evidence for a paracrine/autocrine role for insulin-like growth factor-1 in tooth development. Growth factors1996; 13(1-2): 11-7.

39. Brady G, Crean SJ, Lorenzon A, Kapas S. IGF-1 protects human oral buccal mucosal epithelial cells from sodium nitroprusside-induced apoptosis via PI3kinase. Growth Horm IGF Res 2008; 18(4): 298-306.

40. Bhatavdekar JM, Patel DD, Vora HH, Balar DB. Circulating markers and growth factors as prognosticators in men with advanced tongue cancer. Tumour Biol 1993; 14(1): 55-8.
41. Brady G, O'Regan E, Miller I, Ogungbowale A, Kapas $S$, Crean SJ. Serum levels of insulin like growth factors (IGFs) and their binding proteins (IGFBP's)-1,-2,-3, in oral cancer. Int J Maxillofac Surg 2007; 36(3):259-62.

42. Papadimitrakopoulou VA, Brown EN, Liu DD, et al. The prognostic role of loss of insulin-like growth factor-binding protein-3 expression in head and neck carcinogenesis. Cancer Lett 2006; 239(1): 136-143.

43. Brady G, Crean SJ, Naik P, Kapas S. Upregulation of IGF-2 and IGF-1 receptor expression in oral cancer cell lines. Int J Oncol 2007; 31(4): 875-81.

44. Wu X, Zhao H, Do KA, Johnson MM, Dong Q, Hong WK, Spitz MR. Serum levels of insulin growth factor (IGF-I) and IGF-binding protein predict risk of second primary tumors in patients with head and neck cancer. Clin Cancer Res 2004; 10(12): 3988-95.

45. Slomiany MG, Black LA, Kibbey MM, Tingler MA, Day TA, Rosenzweig SA. Insulin-like growth factor-1 receptor and ligand targeting in head and neck squamous cell carcinoma. Cancer Lett 22007; 48(2): 269-279.

46. Reszec J, Duraj E, Koda M, Musitowicz B, Sulkowska M. Insulin-like growth factor-1 receptor in human oral cancer. Rocz Akad Med Bialymst 2004; 49(Suppl 1): 58-60.

47. Freier S, Weiss O, Eran M, Flyvbjerg A, Dahan R, Nephesh I, Safara T, Shiloni E, Raz I. Expression of the insulin-like growth factors and their receptors in adenocarcinoma of the colon. Gut 1999; 44(5): 704-8.

48. Weber MM, Fottner C, Liu SB, Jung MC, Engelhardt D, Baretton GB. Overexpression of the insulin-like growth factor I receptor in human colon carcinomas. Cancer 2002; 95(10): 2086-95. 